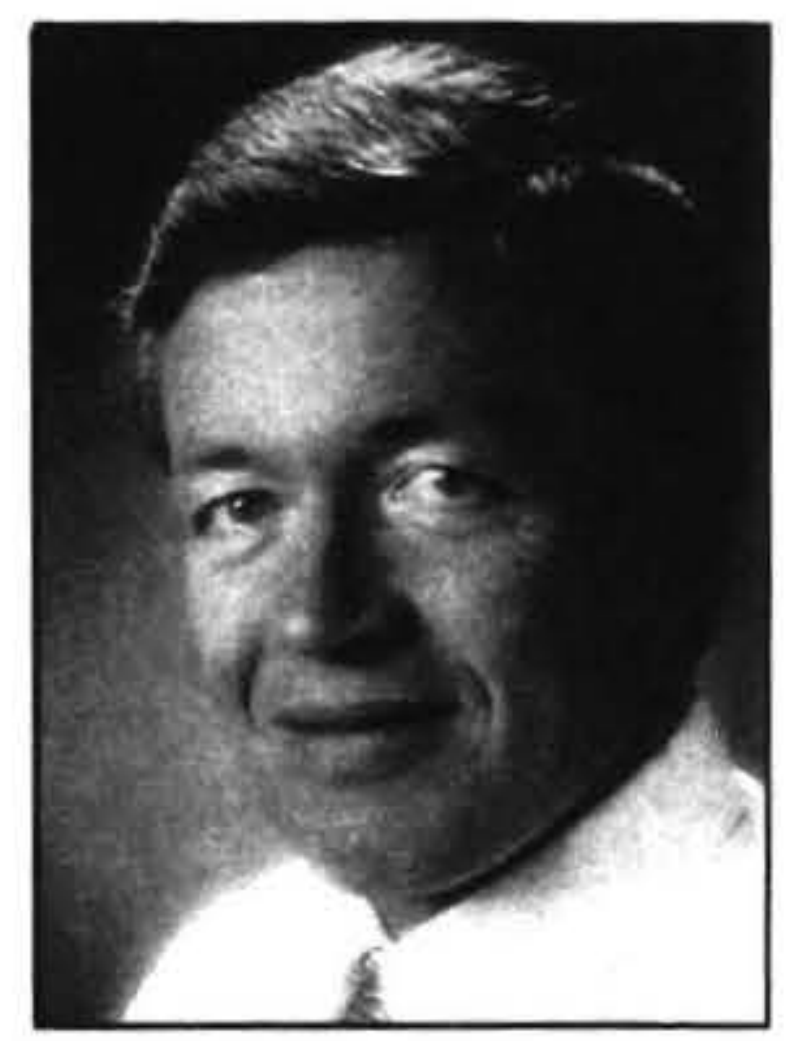

\title{
INTERNATIONAL MIGRATION, POPULATION CHANGE AND THE LABOUR FORCE, 1991-1996: AN OVERVIEW
}

\author{
Richard Bedford, Jacqueline Lidgard and \\ Joanne Young (pictured) \\ Department of Geography, \\ University of Waikato
}

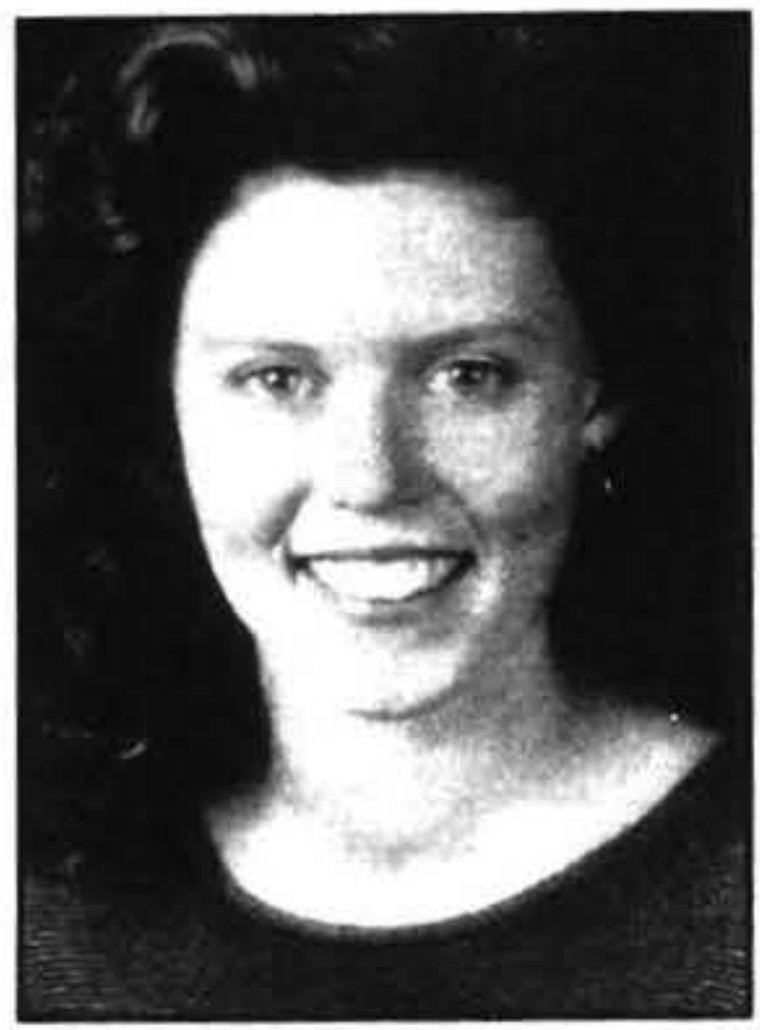

\begin{abstract}
Between March 1991 and March 1996 the de facto population of New Zealand increased by around 225,000, the largest intercensal increase since the early 1970s. A short-lived surge in levels of natural increase in the early 1990s, coupled with some of the highest annual net migration gains since 1975, account for this substantial population growth. While there has been considerable comment in the media about the impact of this growth on the Auckland region in particular, the impacts which it has had on New Zealand's labour force are less well known. This paper examines the components of change in labour force age groups between 1991 and 1996, isolating the impacts of immigration from those of structural change. The contrasting contributions to particular labour force age groups made by emigration of New Zealanders on the one hand, and immigration of citizens from other countries on the other, are then discussed. It is clear from the analysis that emigration and immigration are impacting quite differentially on the younger and older workforces. Some of the implications of these changes are explored with reference to the ageing labour force.
\end{abstract}

The research outlined in this paper is a continuation of an analysis of the impact of international migration during the 1990 s on the labour force age groups which was presented at the Sixth Labour, Employment and Work Conference in 1994 (Bedford and Lidgard, 1995, 223-239). The addition of data relating to the two years ended March 1995 and March 1996 makes it possible to identify the contribution which migration from different parts of the world have made to growth (or decline) in particular labour force age groups during the last intercensal period. These two years saw a marked shift in patterns of emigration of New Zealanders and immigration of citizens of other countries over those reported in the 1994 paper.

Net out-migration of New Zealand citizens has increased sharply in the mid-1990s to reach a level in the year ended March $1996(-35,500)$ which approached that recorded in $1988 / 1989(-36,400)$ when there was considerable concern about loss of skills through emigration. Immigration during $1995 / 96$ from a number of sources, especially northeast Asia (19,650), Australia (14,760), the Pacific Islands $(7,000)$ and the United Kingdom and Ireland $(6,500)$, produced a record net gain of 64,100 citizens from other countries (Bedford, 1996a). In 1996 immigration became an election issue, and there was considerable uncertainty about the impact of such sizeable in-flows on different age groups in the population.

This paper focusses on the impact of international migration on the population aged between 15 and 64 years. The labour force age groups are estimated to have increased by 141,390 between March 1991 and March 1996, a substantially larger increase than during the previous five years $(97,520)$. As is shown later in the paper, 42 percent of the increase in the population aged 15-64 in the first half of the 1990s has been due to international migration. This compares with a contribution of less than 2 percent by net migration to growth in the labour force ages between 1986 and 1991.

Clearly, migration in the 1990 s has had a major impact on a number of dimensions of the labour force, especially its age composition, and the mix of nationalities which comprised certain age groups in the workforce. Particular attention is paid in this paper to the contributions which emigration of New Zealanders and immigration of citizens of other countries have made to the age groups $15-24,25-34,35-44,45-$ 54 and 55-64 years.

The analysis is presented in four parts. A brief methodological note is required to remind the reader of some problems associated with use of arrival and departure data to measure net migration gains and losses. This is followed by an assessment of the contributions to population change made by international migration, on the one hand, and on-going structural change (natural increase and population ageing) on the other, in two five year periods, April 1986 to March 1991 and April 1991 to March 1996. The patterns of New Zealand citizen emigration, and immigration of citizens of other countries during this decade are also summarised in this section.

The third and substantive part of the paper examines the contrasting contributions made to the four age groups specified above by net emigration of New Zealanders and net 
immigration from other countries. Seven source areas for immigrants are identified in this analysis: Australia, the Pacific Islands, Asia (from Afghanistan to Japan), the United Kingdom and Ireland, continental Europe, Africa and the Middle East, and other countries. The extent to which immigration from different parts of the world is substituting for emigration of New Zealanders is established with reference to the four labour force age groups.

The final section of the paper outlines some suggestions for further research on the impact of international migration on the labour force. Data from the 1996 Census of Population and Dwellings will permit a direct analysis of the contributions made by immigrants to particular occupation and industry groups. The re-introduction of the census question on duration of residence in New Zealand will make it possible to differentiate between the very recent immigrants from different countries, and those migrants who have been here some years, in terms of their labour force participation and their types of work. This sort of analysis is impossible using arrival and departure data which can only track the changing contributions made by migration to growth (or decline) in the different labour force age groups.

\section{A methodological note}

The data used in this analysis have been drawn from two sources. Firstly, annual tabulations of arrivals and departures by nationality, five year age group, and sex, obtained from the Client Services Division of Statistics New Zealand, provide the estimates of net migration. The estimates used here refer to total net migration; the balance of all arrivals (including short-term visitors) over all departures in a given period. It must be noted that there is a sampling error associated with any estimates of net migration which include the short-term flows. The magnitude of the error of estimate is not particularly serious where the numbers of arrivals and departures in any particular category are large. In the case of figures cited in this paper, the sampling error problem has been minimised by using reasonably large aggregations of nationalities and age groups. However, it is important to appreciate that the figures cited are not precise estimates of net migration.

The second source of data relates to estimates of the age-sex compostion of the de facto population (the total population in New Zealand) on 31 March for the years 1991 to 1995. These have been obtained from the Demographic Analysis Section of Statistics New Zealand. It is not possible to obtain an estimate of the age-sex distribution of the de facto population for 31 March 1996 until the results of the 1996 Census of Population and Dwellings are released. To facilitate analysis of the five year period 1 April 1991 to 31 March 1996 the estimated age-sex distribution for $31 \mathrm{De}-$ cember 1995 has been used. Quite fortuitously, this estimate gives a total population for New Zealand of 3,643,210 which is only 17,150 less than the provisional total of $3,660,360$ enumerated on 5 March 1996 (Statistics New Zealand, 1996a). Given that the end of March estimate is always below that enumerated in a census at the beginning of the month (March is a month when net emigration is common), the December 1995 estimate is an acceptable surrogate for the total at the end of March 1996.

It is likely that the 1996 enumeration will have produced an undercount of the total New Zealand population. As Statistics New Zealand $(1996 \mathrm{~b}, 6)$ note in a report on the first postenumeration survey to be conducted in this country to measure the level of census coverage: "According to overseas experience, census miscounts have usually resulted in a net undercount. For example, the most recent (1991) national undercount results from four countries were: Australia 1.8 percent, Canada 2.9 percent, UK 2.0 percent, and USA (1990) 1.8 percent."

If there is a 1.8-2.0 percent level of underenumeration in New Zealand, then the March 1996 estimate for the total population, which is used in the following analysis, may be too low. The effect this will have on the analysis is, however, not particularly serious; it will affect the estimate of structural change in the population between 1991 and 1996, not the estimate of net migration. The latter is taken, without amendment, from the arrival and departure data. The balance of population change during the intercensal period is classed as "structural change" - change due to the balance of births over deaths, and the progressive ageing of the population.

\section{Migration and structural change, 1986-1996}

Between 1 April 1986 and 31 March 1996 the population of New Zealand is estimated to have increased by around 354,200 (Table 1). Almost two thirds of this increase (63.5 percent) occurred between 1 April 1991 and 31 March 1996. Over the same period, the population in the labour force age groups (15-64 years) is estimated to have increased by just under 240,000 , and 59 percent of this growth took place in the last intercensal period (Table 1).

The major component of population change in both periods was structural change. In fact, between 1986 and 1991 the increase due to structural change was larger than the overall population growth because there was a small net migration

Table 1: Population Change, 1986-1996

\begin{tabular}{lll}
\hline Year/Period & Total Population & $\begin{array}{l}\text { Labour Force } \\
\text { Ages }\end{array}$ \\
\hline 31 March 1986 & $3,289,020$ & $2,145,880$ \\
31 March 1991 & $3,418,300$ & $2,243,400$ \\
31 March 1996 & $3,643,210$ & $2,384,990$
\end{tabular}

Change

\begin{tabular}{lrr}
$1986-1991$ & 129,280 & 97,520 \\
$1991-1996$ & 224,910 & 141,390 \\
$1986-1991$ & 354,190 & 238,910 \\
$\% 1991-1996$ & 63.5 & 59.2 \\
\hline
\end{tabular}

Source: Unpublished tables, Statistics New Zealand 
Table 2. Components of population change

\begin{tabular}{lll}
\hline Year/Period & Total Population & $\begin{array}{l}\text { Labour } \\
\text { Force Ages }\end{array}$ \\
\hline
\end{tabular}

Structural Change

1986-1991

1991-1996

131,230

149,070

1986-1996

280,300

95,670

81,560

International Migration

1986-1991

1991-1996

$-1,960$

75,800

1,840

59,820

1986-1996

73,840

61,660

Source: Unpublished tables, Statistics New Zealand

loss (Table 2). In the labour force ages net migration added a small number to population growth in the late 1980s, but this was very small compared with the contribution made by net migration in the early 1990s. Between 1991 and 1996 net migration added almost 76,000 or 33.7 percent to total population growth. Almost 60,000 of this was in the labour force ages (Table 2).

The respective contributions which structural change and net migration made to changes in the populations in different age groups in these two periods are summarised in Table 3. It is interesting to note the considerable irregularity in these contributions, both between the two periods, and between the two causes of population change. New Zealand's population structure is highly unstable, largely as a result of significant fluctuations in fertility levels since the late 1930s (Pool and Bedford, 1996).

This instability makes it very difficult to forecast how international migration during a particular period will impact on the age composition of the population. It is clear from the data on structural change in Table 3 that a number of "bulges" and "contractions" in the age structure are working their way through the population, producing significant surpluses, followed by major deficits in specific age groups in successive five year periods. These bulges and contractions are augmented differentially by age-specific net migration gains and losses which, in the late 1980s and early 1990s, show little consistency over time.

A couple of examples from the labour force age groups illustrate the complexity of age-specific population change in New Zealand in the last decades of the twentieth century. Between 1986 and 1991 the age group 30-34 years increased by 20,560 as a result of structural change. This growth was augmented by the addition of a further 8,010 as a result of international migration to produce an aggregate change in the age group of 28,570 . During the next five years, the total number in this age group grew by 17,750 . There was actually a decline in numbers due to structural change by almost 3,000. International migration, on the other hand, added 20,640 to produce the overall increase of 17,750 .
Table 3. The age-sex composition of population change, 1986-1996

\begin{tabular}{lrrrr}
\hline Age Group & \multicolumn{2}{c}{ Structural Change } & \multicolumn{2}{c}{ International } \\
& & & \multicolumn{2}{c}{ Migration } \\
& $1986-91$ & $1991-96$ & $1986-91$ & $1991-96$ \\
\hline $0-4$ & 35,500 & 8,690 & $-6,500$ & 5,130 \\
$5-9$ & $-3,930$ & 27,940 & 2,390 & 4,500 \\
$10-14$ & $-37,370$ & $-6,590$ & 2,190 & 9,650 \\
$15-19$ & $-13,580$ & $-37,900$ & -400 & 10,670 \\
$20-24$ & 7,600 & 15,540 & $-15,380$ & $-7,930$ \\
$25-29$ & $-6,020$ & $-11,310$ & 14,710 & 14,560 \\
$30-34$ & 20,560 & $-2,890$ & 8,010 & 20,640 \\
$35-39$ & 5,350 & 37,770 & 1,770 & 11,800 \\
$40-44$ & 46,980 & 7,180 & $-1,170$ & -980 \\
$45-49$ & 25,830 & 49,850 & $-4,110$ & 830 \\
$50-54$ & 17,500 & 18,660 & $-1,340$ & 5,370 \\
$55-59$ & $-11,710$ & 13,450 & 800 & 1,620 \\
$60-64$ & 3,160 & $-8,780$ & $-1,040$ & 3,230 \\
$65-69$ & 15,560 & 2,780 & $-2,790$ & 3,860 \\
$70-74$ & 3,540 & 13,420 & 830 & -550 \\
$75+$ & 22,260 & 21,260 & 70 & $-6,600$ \\
\hline Total & 131,230 & 149,070 & 1,960 & 75,800 \\
\hline
\end{tabular}

Source: Unpublished tables, Statistics New Zealand

The combined contributions of structural change and international migration $(28,570)$ between 1986 and 1991 represented 11.5 percent of the total number in the age group at the beginning of the period $(248,720)$. In the case of the next five year period (1991-96), the combined contributions of these two components of population change $(17,750)$ represented only 6.3 percent of the total aged 30-34 on 31 March $1991(277,290)$

The 35-39 year age group moved in a different direction. Between 1986 and 1991 the numbers in their late 30s increased by 5,350 as a result of structural change, and a further 1,770 through net migration gains. In the first half of the 1990s, however, structural change added over 37,000 to this age group, while international migration added a further 11,800 . The respective aggregate contributions of structural change and international migration to growth in numbers in their late 30 s during the two five year periods are: 2.9 percent (1986-91) and 19.6 percent (1991-96)

There is one further complicating factor with regard to the migration dimension of population change, and that is the fact that the net migration gains and losses by age group are the result of two quite contradictory migrant flows. The first is the out-migration of New Zealanders. In all years between 1 April 1986 and 31 March 1996, except the year ended 31 March 1991, there have been net losses of New Zealand citizens. The second migrant flow is the net immigration of citizens of other countries. In all years during the decade under discussion in this section, the number of arrivals of non-New Zealanders has exceeded the number of departures, often by quite significant amounts. The net effect of 
Table 4. Composition of the net migration gains and losses, 1991-1996

\begin{tabular}{lrrr}
\hline Age Group & NZ Citizens & $\begin{array}{l}\text { Other } \\
\text { Nationalities }\end{array}$ & Total \\
\hline $0-4$ & $-7,960$ & 13,100 & 5,140 \\
$5-9$ & $-4,120$ & 8,620 & 4,500 \\
$10-14$ & $-5,340$ & 14,990 & 9,650 \\
$15-19$ & $-8,430$ & 19,100 & 10,670 \\
$20-24$ & $-28,240$ & 20,310 & $-7,930$ \\
$25-29$ & -830 & 15,390 & 14,560 \\
$30-34$ & -470 & 21,110 & 20,640 \\
$35-39$ & $-7,500$ & 19,300 & 11,800 \\
$40-44$ & $-8,580$ & 7,600 & -980 \\
$45-49$ & $-8,910$ & 9,740 & 830 \\
$50-54$ & -580 & 5,960 & 5,370 \\
$55-59$ & $-2,030$ & 3,650 & 1,620 \\
$60-64$ & 510 & 2,730 & 3,230 \\
$65-69$ & -360 & 4,230 & 3,860 \\
$70-74$ & $-1,720$ & 1,170 & -550 \\
$75+$ & 1,210 & $-7,810$ & $-6,600$ \\
\hline Total & $-83,360$ & 159,200 & 75,840 \\
\hline
\end{tabular}

Source: Unpublished tables, Statistics New Zealand.

these two contrasting flows, is for them to partially cancel each other out. This is illustrated with reference to migration flows between 1991 and 1996 in Table 4.

The problem with just focussing on the overall net migration gains and losses by age group is that they tell us nothing of the mix of New Zealand citizens and non-citizens in the migration contribution - a mix which is clearly not consistent by age group, as is evident in Table 4. Within the noncitizen component there is also significant diversity of peoples, and this diversity changes over time.

Between 1991 and 1996 there was heightened awareness in New Zealand of Asian immigration, and by late 1995 public comment on the impact of Asian migration on New Zealand's schools, hospitals and labour force was becoming quite vociferous. Yet, as has been shown elsewhere (Bedford, 1996a; Bedford and Pool, 1996), the overall net contribution of citizens from Asian countries during the calendar year, 1995, was no greater than the contribution made by "white" migrants from countries such as Australia, the United Kingdom, South Africa and the members of the European Union. Indeed, over the entire intercensal period, the net migration gain from sources of essentially "white" migrants accounted for 43 percent of the total immigrant contribution to labour force change.

The age compositions of the net migration gains and losses, by "white" migrant sources (excluding New Zealand citizens), and by other sources, are summarised in Table 5 for the period 1991-1996. While the majority (57 percent) of the net gain was made up of citizens of Asian, Pacific, African (excluding South Africa) and Middle East countries, the "white" migrant sources continued to make a very signifi- cant contribution. The mix of migrants from the two clusters of source areas varied quite markedly by age group; those from "white" source areas dominated at the youngest ages $(0-4)$, the mid- 20 s to late- $30 \mathrm{~s}$, the $50 \mathrm{~s}$, and the late- $60 \mathrm{~s} / \mathrm{early}-$ 70 s (Table 5). Migrants from other sources dominated in the 5-24 year age groups, the 40 s and the early 60 s.

These summary data on the contributions to population change in recent years made by structural change and international migration, and by different groups within the net migration gains and losses, demonstrate the need for a comprehensive assessment of the demographic impact of overseas population flows on New Zealand's labour force. This is particularly important in the context of the government's efforts to regulate immigration in terms of some quite specific policy objectives. The annual targets set for new immigrant approvals need to be assessed regularly in terms of the actual contributions which net migration is making not only to the size of New Zealand's population, but also its age composition.

\section{The contributions of net migration to the la- bour force, 1991-96}

It has been shown that between 1991 and 1996 the population aged 15-64 years increased by an estimated 141,390 (Table 1). Forty two percent of this increase $(59,820$ ) was due directly to net international migration (Table 2). The overall net loss of New Zealand citizens aged between 15-64 years was $-65,060$. This was off-set by a net migration gain of 124,890 citizens of other countries, just under double the number of New Zealanders "lost" to the labour force age groups through net emigration. However, the extent to

Table 5. Composition of the 'other nationalities' component of net migration, 1991-1996

\begin{tabular}{lrrrr}
\hline $\begin{array}{l}\text { Age } \\
\text { Group }\end{array}$ & $\begin{array}{r}\text { 'White' } \\
\text { sources }\end{array}$ & $\begin{array}{l}\text { Other } \\
\text { sources }\end{array}$ & Total & \multicolumn{2}{l}{$\begin{array}{l}\text { \%'White' } \\
\text { sources }\end{array}$} \\
\hline $0-4$ & 7,070 & 6,030 & 13,100 & 54.0 \\
$5-9$ & 1,460 & 7,160 & 8,620 & 16.9 \\
$10-14$ & 3,960 & 11,030 & 14,990 & 35.9 \\
$15-19$ & 3,080 & 16,020 & 19,100 & 16.1 \\
$20-24$ & 8,400 & 11,910 & 20,310 & 41.4 \\
$25-29$ & 9,670 & 5,720 & 15,390 & 62.8 \\
$30-34$ & 11,840 & 9,270 & 21,110 & 56.1 \\
$35-39$ & 10,180 & 9,120 & 19,300 & 52.7 \\
$40-44$ & 2,480 & 5,120 & 7,600 & 32.6 \\
$45-49$ & 4,450 & 5,290 & 9,740 & 45.7 \\
$50-54$ & 3,210 & 2,750 & 5,960 & 53.8 \\
$55-59$ & 1,790 & 1,860 & 3,650 & 49.0 \\
$60-64$ & 570 & 2,160 & 2,730 & 20.8 \\
$65-69$ & 2,440 & 1,790 & 4,230 & 57.7 \\
$70-74$ & 1,660 & -490 & 1,170 & 100.0 \\
$75+$ & $-3,600$ & $-4,190$ & $-7,790$ & 46.2 \\
\hline Total & 68,660 & 90,550 & 159,210 & 43.1 \\
\hline
\end{tabular}

Source: Unpublished tables, Statistics New Zealand 
which net immigration of citizens of other countries off-sets the net losses of New Zealand citizens is not consistent by age group.

In the discussion which follows, the net gains and losses of New Zealand citizens in five labour force age groups (15-24, $25-34,35-44,45-54,55-64)$ are placed alongside the gains of citizens from other countries, shown separately for major sources, in order to indicate which immigrant groups are contributing most to the replacement of emigrant New Zealand citizens in the labour force. There can be a tendency for the debate about the impact of international migration on population change to ignore the flows of New Zealanders and focus only on new arrivals. This can result in an overemphasis on the numerical impact of immigrant flows on different segments of the labour force.

\section{The "younger" labour force age groups}

Between 1991 and 1996 it is estimated that the population aged 15-24 years declined by almost 20,000 while the numbers aged 25-34 years increased by 21,010 (Table 6). Both age groups experienced significant declines due to structural change, and the explanation for the quite different overall growth trends is due almost entirely to international migration.

The age group 15-24 experienced a significant net loss of New Zealand citizens which was exceeded slightly by net immigration of "other citizens" from overseas. The overall net gain was only 2,740 . In the case of the age group 25-34 the net loss of New Zealand citizens was very small $(-1,300)$, ensuring that most of the net gain from overseas immigration $(36,510)$ contributed directly to population growth (Table $6)$.

The composition of the "other citizens" (hereafter referred to as OC) net gains in the two age groups differed quite markedly in terms of sources and gender balance of immigrants. In both age groups, net gains of citizens of Asian countries accounted for the largest share of the total OC net immigration of (Table 6). In the case of the 15-24 year age group, Asian citizens $(22,880)$ accounted for 58 percent of the OC net immigration, while in the age group 25-34 Asian citizens $(11,420)$ contributed 31 percent of the total net gain of other citizens. The second and third ranking sources, in terms of magnitude of net immigration were Europe $(4,370)$ and the Americas $(4,060)$ for the age group 15-24 years, while citizens of Australia $(11,320)$ and the United Kingdom and Ireland $(6,600)$ were prominent in the 25-34 year age group.

In terms of gender balance, there was a larger net gain of women than men in the other citizen group aged $15-24$ years, producing a sex ratio of 84.3 males per 100 females. This is a very low sex ratio compared with that for other age groups. In the case of the 25-34 year net migrant group, males outnumbered females and the sex ratio was 140.2 (Table 6). The gender mix amongst the net OC immigrant populations differed both by age group and by source area there is little consistency in the patterns which makes gener-

Table 6. Changes in the younger labour force age groups, 1991-1996

\begin{tabular}{|c|c|c|c|}
\hline \multirow[t]{2}{*}{ Characteristic } & \multicolumn{3}{|c|}{ Age Group } \\
\hline & $15-24$ & $25-34$ & $15-34$ \\
\hline Population change & $-19,620$ & 21,010 & 1,390 \\
\hline Structural change & $-22,360$ & $-14,200$ & $-36,560$ \\
\hline Net migration & 2,740 & 35,210 & 37,950 \\
\hline Net migration & 2,740 & 35,210 & 37,950 \\
\hline NZ citizens & $-36,670$ & $-1,300$ & $-37,970$ \\
\hline Other citizens (OC) & 39,410 & 36,510 & 75,920 \\
\hline Sources of other citizens & 39,410 & 36,510 & 75,920 \\
\hline Australia & 2,100 & 11,320 & 13,420 \\
\hline Pacific Islands & 3,780 & 1,590 & 5,370 \\
\hline Asia & 22,880 & 11,420 & 34,300 \\
\hline Americas & 4,060 & 360 & 4,420 \\
\hline UK/Ireland & 20 & 6,600 & 6,620 \\
\hline Europe & 4,370 & 1,690 & 6,060 \\
\hline Africa/Middle East & 2,150 & 3,400 & 5,550 \\
\hline Other countries & 50 & 130 & 180 \\
\hline Gender balance (OC) & 39,410 & 36,510 & 75,920 \\
\hline Males & 18,030 & 21,310 & 39,340 \\
\hline Females & 21,380 & 15,200 & 36,580 \\
\hline Sex ratio & 84.3 & 140.2 & 107.5 \\
\hline
\end{tabular}

Source: Unpublished tables, Statistics New Zealand 
alisation about the impact of net immigration on the compositions of labour force age groups difficult.

When the two younger labour force ages are combined, it can be seen that net immigration of citizens of Asian countries accounted for 34,300 ( 45 percent) of the 75,920 OC net gain between 1991 and 1996 (Table 6). This is a somewhat lower share of the total than might have been expected, given the emphasis placed on Asian immigration in the early 1990s. More surprising is the sizeable influx of Australian citizens aged between 15 and 34 years $(13,420$ or 17.6 percent of the total OC net gain). Much of this contribution came from a surplus of short-term arrivals over departures, especially in 1995 and 1996. It will be interesting to explore aspects of trans-Tasman immigration to New Zealand in recent years once data collected in the 1996 Census of Population and Dwellings become available for analysis.

The "mediatric" labour force age groups

The two age groups which span the "middle" or mediatric labour force ages both experienced very significant structural growth between 1991 and 1996 (Table 7). In the case of the 35-44 year age group, structural change $(44,940)$ accounted for 80.5 percent of the total growth $(55,770)$, with net migration $(10,830)$ accounting for 19.5 percent. The $45-$ 54 year age group gained even more from structural change (91.7 per cent of the total change of 74,710 ). Net migration made a very modest contribution ( 8.2 percent) to growth in this age group.
Net losses of New Zealanders were more than compensated for by immigration from overseas; indeed net gains of citizens from Asian countries "replaced" most of the losses of New Zealanders aged 35-44 and 45-54 (Table 7). Gains from Australia continued to be quite high for both age groups (8,200 aged $35-44$ and 4,580 aged $45-54$ years). The other significant contributions to the $O C$ net gain aged $35-44$ came from Africa and the Middle East (especially South Africa) and the United Kingdom and Ireland (Table 7). The Americas were the third ranked source for net gains of overseas immigrants aged 45-54 - indeed this source was almost as significant as Australia for the contribution made by OC net migration to growth in the age group.

The sex ratio of the younger mediatric age group was much less distorted than that for the older group (121.8 compared with 960.8 males per 100 females). Clearly male domination of net migration gains of other citizens gets much more marked in the older age groups. As can be seen from Table 8 , the sex ratio of the overseas net migrant population aged 55-64 was 2,795 males per 100 females. The contribution which overseas immigration between 1991 and 1996 made to the progressive ageing of New Zealand's labour force age groups (and population in general) was biased strongly in favour of males.

The impact of structural change and net migration on the population aged 35-54 is summarised in the last column of Table 7 . Net migration contributed only 17,030 (13 percent)

Table 7. Changes in the mediatric labour force age groups, 1991-1996

\begin{tabular}{|c|c|c|c|}
\hline \multirow[t]{2}{*}{ Characteristic } & \multicolumn{3}{|c|}{ Age Group } \\
\hline & $35-44$ & $45-54$ & $35-54$ \\
\hline Population change & 55,770 & 74,710 & 130,480 \\
\hline Structural change & 44,940 & 68,510 & 113,450 \\
\hline Net migration & 10,830 & 6,200 & 17,030 \\
\hline Net migration & 10,830 & 6,200 & 17,030 \\
\hline NZ citizens & $-16,070$ & $-9,500$ & $-25,570$ \\
\hline Other citizens (OC) & 26,900 & 15,700 & 42,600 \\
\hline Sources of other citizens & 26,900 & 15,700 & 42,600 \\
\hline Australia & 8,200 & 4,580 & 12,780 \\
\hline Pacific Islands & 540 & -540 & 0 \\
\hline Asia & 12,350 & 8,340 & 20,690 \\
\hline Americas & -100 & 4,290 & 4,190 \\
\hline UK/reland & 2,260 & $-1,120$ & 1,140 \\
\hline Europe & 190 & -580 & -390 \\
\hline Africa/Middle East & 3,210 & 870 & 4,080 \\
\hline Other countries & 250 & -140 & 110 \\
\hline Gender balance (OC) & 26,900 & 15,700 & 42,600 \\
\hline Males & 14,770 & 14,220 & 28,990 \\
\hline Females & 12,130 & 1,480 & 13,610 \\
\hline Sex ratio & 121.8 & 960.8 & 213.0 \\
\hline
\end{tabular}

Source: Unpublished tables, Statistics New Zealand 
to the overall growth of 130,480 in this age group. This contrasts sharply with the role migration played in the younger labour force age groups (Table 6). The total net migration gain from overseas sources in the age group 35-54 $(42,600)$ was just over half the size of that in the age group $15-34(75,920)$.

The contribution made by citizens from Asian countries $(20,690)$ to the total net gain of other citizens was slightly higher in percentage terms (48.5) than it was in the younger age group (45.2 percent). Net immigration of Australian citizens aged 35-54 (12,780) was almost as large numerically as it was in the younger group $(13,420)$. Europe and the United Kingdom/Ireland were not nearly as significant as sources of immigrants in the mediatric age group as they were in the younger one. The Americas and Africa/Middle East were much more prominent (Table 7).

\section{The "older" labour force and an overall assessment}

Population change in the age group was quite small during the early 1990s. The numbers aged between 55 and 64 increased by an estimated 9,520 with almost equal shares in the increase coming from structural change $(4,670)$ and international migration $(4,850)$ (Table 8 ). A low level of growth in the older labour force is to be expected; these are the survivors of the low fertility years of the 1930s.

A small net loss of New Zealand citizens was generously

\section{Table 8. Changes in labour force aged 55-64 and 15-64 years, $1991-1996$}

\begin{tabular}{|c|c|c|}
\hline \multirow[t]{2}{*}{ Characteristic } & \multicolumn{2}{|c|}{ Age Group } \\
\hline & $55-64$ & $15-64$ \\
\hline Population change & 9,520 & 141,39 \\
\hline Structural change & 4,670 & 81,560 \\
\hline Net migration & 4,850 & 59,830 \\
\hline Net migration & 4,850 & 59,830 \\
\hline NZ citizens & $-1,520$ & $-65,060$ \\
\hline Other citizens (OC) & 6,370 & 124,890 \\
\hline Sources of other citizens & 6,370 & 124,890 \\
\hline Australia & 850 & 27,050 \\
\hline Pacific Islands & 340 & 5,720 \\
\hline Asia & 3,460 & 58,450 \\
\hline Americas & -420 & 8,170 \\
\hline UK/Ireland & -760 & 7,030 \\
\hline Europe & 2,380 & 8,040 \\
\hline Africa/Middle East & 640 & 10,270 \\
\hline Other countries & -110 & 160 \\
\hline Gender balance (OC) & 6,370 & 124,890 \\
\hline Males & 6,150 & 74,480 \\
\hline Females & 220 & 50,410 \\
\hline Sex ratio & 2795.5 & 147.7 \\
\hline
\end{tabular}

Source: Unpublished tables, Statistics New Zealand replaced by immigration, especially of citizens of Asian and European countries. A large part of this immigration would be for family reunion purposes; people aged over 55 years do not meet the criteria for entry under the general points system which has been in place since November 1991 (Farmer, 1997; NZIS, 1997). In addition to the OC net gains from Asia and Europe in the 55-64 year age group, there were also net losses to the Americas and the United Kingdom and Ireland. Some of these people are likely be return migrants going "home" after a lengthy stay in New Zealand, especially those who are from the United Kingdom.

Reference has already been made to the gender imbalance in the OC net gain for the older labour force age group ( 2795.5 males per 100 females). This arises from two very different patterns of short-term net migration by sex in virtually all the source areas. Whereas there is almost always a net gain of males aged 55-64 in the OC migration flows to New Zealand, especially from Australia, Asia and Europe, in the case of females, there are frequently net losses. These net losses are largely due to short-term movements of citizens of other countries who have New Zealand residence status. In other words, amongst the population aged 55-64 years, there are more sizeable net losses of female New Zealand resident Samoans, Hong Kong Chinese, British citizens and so on, who depart for a short stay overseas, than there are amongst male New Zealand residents who hold passports valid in other countries.

When the labour force age groups are considered as a single population (15-64 years), it can be seen that international migration has contributed 59,830 (42 percent) of the total estimated growth of 141,390 between 1991 and 1996 (Table 8). Immigration from overseas sources produced a net gain $(124,890)$ which was almost double the net loss $(-65,060)$ of New Zealand citizens. Net gains of citizens from countries in Asia $(58,450)$ accounted for 47 percent of this OC total, with Australian citizens $(27,050)$ contributing a further 22 percent (Table 8). The other two important sources of immigrants in the labour force age groups were firstly, Europe and the United Kingdom/Ireland $(15,080)$, and secondly, Africa and the Middle East $(10,270)$. The island countries of the Pacific were not a major source of net migration gains during the early 1990 s; indeed, immigration from the Americas $(8,190)$ contributed more to net gains in the labour force age groups than migration from the Pacific $(5,720)$ during this period (Table 8$)$.

\section{Conclusion}

This attempt to unravel the contributions which international migration is making to changes in the size and composition of the population aged between 15 and 64 years has demonstrated that simple generalisations about the impact of recent net gains, especially from countries in Asia, are unwise. The highly unstable age-sex composition of the New Zealand population makes it necessary to isolate for each age group the respective contributions made by ongoing structural change on the one hand, and net migration gains and losses on the other. Only when these contributions can be assessed in tandem can the relative importance of 
international migration for population change in particular age groups be established.

Given the attemtion which has been focussed in recent years on immigration from countries in the vast region termed "Asia", it is also important to attempt to establish the relative importance of net gains from all sources of migrants. It is clear from this analysis that while citizens from countries in Asia (especially northeast Asia) have made the largest numerical contributions to the $\mathrm{OC}$ net gains in all of the age groups considered in this paper, rarely have these gains exceeded 50 percent of the total recorded for citizens of other countries. Indeed, it was only in the age group 15-24 years that citizens of countries in Asia comprised more than half (58 percent) of the OC total net gain. Immigration from traditional sources (Australia, the United Kingdom and Ireland, and other European countries) continues to make a major contribution to growth in the labour force age groups.

Without doubt, there has been considerable diversification in the sources of New Zealand's immigrants since the substantive review of immigration policy in 1986, and the implementation of the points system in 1991 (Population Monitoring Group, 1991; Bedford, 1993 and 1996b; Farmer, 1996 and 1997). New sources of migrants, especially countries in southeast Asia (1986-1991) and northeast Asia (1991-1996), are changing the human face of New Zealand's population and its labour force. During the early 1990s net migration gains from overseas sources have ensured that the youthful labour force has not experienced the numerical declines that might have occurred as a result of structural change and emigration of New Zealanders. In the mediatric and older labour force age groups, international migration has augmented growth due to structural change, and is contributing, in the longer term, to the progressive ageing of the New Zealand population (Pool and Bedford, 1996).

\section{Future research}

The implications of international migration for the growth and structural transformation of New Zealand's population continue to be monitored as part of the FRST-funded New Demographic Directions Programme which is based in the Population Studies Centre at the University of Waikato. During 1997 and 1998 attention will be focussed on the analysis of data collected on migrants in the 1996 Census of Population and Dwellings. Reference has already been made in this paper to the fact that arrival and departure data do not permit analysis of the occupational composition of immigrant populations. It is not possible to isolate the direct contribution immigration makes to the economically active populationin different age groups using these data.

Analysis of the labour force participation of immigrants resident in New Zealand at the time of the 1996 census will be possible at both national and sub-national levels. A question on duration of residence in New Zealand was reinstated in the 1996 census questionnaires after being removed in 1991. Responses to this question, when analysed in association with data collected on country of usual resi- dence in 1991, country of birth, ethnicity, age, sex, employment status, work status, occupation, industry, and income will allow for some quite fine-grained explorations of immigrants in the New Zealand workforce.

There is a need to specify more precisely just how immigrants are participating in the New Zealand economy. The points-based immigration system, and the targets for new immigrants, are rooted in a number of assumptions about the contribution which international migration makes to economic growth and social cohesion (NZIS, 1995). Recent developments in the systems for collecting and analysing information provided by people seeking approval under the points system to settle in New Zealand will also offer opportunities for innovative research into the mobility behaviour of recent immigrants. The New Zealand Immigration Service is developing a system for linking their data on residence approvals to the arrival and departure data collected and processed by Statistics New Zealand.

It will be a few years before a data base with sufficient timedepth is available for substantive research into the migration behaviour of different groups of settlers in New Zealand. However, there is enormous potential for much more meaningful analysis using the data bases compiled by the New Zealand Immigration Service on the issuing of visas and permits, and the data bases compiled by Statistics New Zealand on arrivals and departures, once these two are linked. There is certainly plenty of scope for future research into the impacts of international migration on the New Zealand labour force using 1996 census data, the new data bases being established by NZIS, and the on-going in-depth household survey research which forms part of specific research activities such as the FRST-funded New Demographic Directions Programme.

\section{References}

Bedford, R.D. 1993 Migration and restructuring: reflections on New Zealand in the 1980s. New Zealand Population Review, 19 (1\&2):1-14.

Bedford, R.D. 1996a International migration, 1995: some reflections on an exceptional year. New Zealand Journal of Geography No. 101: 21-33.

Bedford, R.D. 1996b International migration and national identity. In R. Le Heron and E. Pawson (eds) Changing Places: New Zealand in the Nineties, Longmans, Auckland: 350-360.

Bedford, R.D. and Lidgard, J.M. 1995 International migration and population change in the 1990s: a new regime? in P.S. Morrison (ed.) Labour Employment and Work in New Zealand. Proceedings of the Sixth Conference 24-25 November, 1994, Victoria University of Wellington: 233-239.

Bedford, R.D. and Pool, D.I. 1996 'Asian invasion' myth only one part of a complex story. National Business Review, 19 May 1996:16. 
Farmer, R.S.J. 1996Economic deregulation and changesin NewZealand's immigration policy: 1986 to 1991. People and Place, 4(3): 55-63.

Farmer, R.S.J. 1997 New Zealand's 'targeted' immigration policy, 1991to 1996. People and Place, 5(1):1-15.

Lidgard, J.M. 1993 Neglected international migrants: a study of returning New Zealanders. New Zealand Population Review, 19 (1\&2):94-121.

Lowe, R.J. 1991 Supplement to 'On the Move: Migration and Population Trends and Policies' Population Monitoring Group Technical Working Paper, New Zealand Planning Council, Wellington.

New Zealand Immigration Service (NZIS) 1995 Background Paper. A Review of New Zealand's Residence Policies: the 'Targeted' Immigration Streams. Unpublished Report, NZIS, Wellington.

New Zealand Immigration Service (NZIS) 1997 Immigration Fact Pack, Issue 7, March 1997, 8 pp.

Pool, D.I. and Bedford, R.D. 1996 Macro social change in New Zealand: historical and international contexts. Population Studies Centre Discussion Paper No. 18, University of Waikato, Hamilton.

Statistics New Zealand 1996a 1996 Census of Population and Dwellings: Provisional Results. Hot Off the Press, 31 May 1996, Information Consultancy Group, Christchurch.

Statistics New Zealand 1996b 1996 Post-Enumeration Survey and Post-Censal Population Estimates. Population and Demography Division, Christchurch.

\section{Author}

Richard Bedford is Professor of Geography, Geography Department, University of Waikato, Private Bag 3105, Hamilton. Jacqueline Lidgard and Joanne Young are research fellows in the same department. 